\title{
Influence of Organic Derivatives on Direct Regeneration of finger millet genotype CO 9
}

\author{
G. Atul Babu ${ }^{1}$, R. Ravindhran ${ }^{2 *}$ \\ ${ }^{1,2}$ T.A.L. Samy Unit for Plant Tissue Culture and Molecular Biology, Department of Plant Biology and Biotechnology, Loyola \\ College (Autonomous), Affiliated To University of Madras, Chennai 600 034, Tamil Nadu, INDIA \\ Corresponding author: raviloyola1998@gmail.com
}

Available online at: www.isroset.org

Received: 22/Jul/2019, Accepted: 18/Aug/2019, Online: 31/Aug/2019

\begin{abstract}
Finger millet (Eleusine coracana (L.) Gaertn.) is a commercially important food crop extensively cultivated in the arid and semi-arid tropical regions of India and East Africa. The current study was designed to develop an efficient protocol for micropropagation by the influence of additives to enhance the number of shoots per explant from Shoot Apical Meristems (SAMs) of finger millet genotype CO 9. The highest shoot regeneration frequency (95.89\%) with an average of 46.52 shoots per explant and $10.86 \mathrm{~cm}$ shoot length per explant was achieved when SAMs were cultured in Shoot Regeneration Medium (SRM) containing Murashige and Skoog's (MS) medium supplemented with $3.0 \mathrm{mg} / \mathrm{L}$ 6-Benzyl Amino Purine (BAP), 2.0 $\mathrm{mg} / \mathrm{L}$ Kinetin and $5 \%$ coconut water, $300 \mathrm{mg} / \mathrm{L}$ proline and $400 \mathrm{mg} / \mathrm{L}$ casein enzymatic hydrolysate, and $3 \mathrm{mg} / \mathrm{L}$ glycine. Subculturing the SAMs in SRM at 2 weeks interval for 8 weeks resulted in an increase in the number of shoots per explant. The highest rooting frequency $(100 \%)$ with an average root length of $7.32 \mathrm{~cm}$ was obtained on full-strength MS medium supplemented with $0.25 \mathrm{mg} / \mathrm{L}$ IAA. and successfully acclimated in the field, subsequently developed into fertile plants. Thus, the procedure described is a rapid and consistent method useful for efficient large-scale propagation and genetic transformation in finger millet.
\end{abstract}

Keywords- Eleusine coracana, shoot apical meristems, Shoot Regeneration Medium, Random amplified polymorphic DNA

\section{INTRODUCTION}

Finger millet (Eleusine coracana [L.] Gaertn.), a small grain crop, cultivated in more than 4 million ha worldwide is the staple diet for underdeveloped populations of Africa [1]. Millets are coarse-grained hardy crops of the Poaceae (Gramineae) family that include 10 genera and 14 species. Millets are the first domesticated crops of the tropics owing to their rapid growth, minimal harvesting period, and tolerance to abiotic stress like drought and high temperatures [2-3]. Compared to other cereal crops, Finger millet rich in amino acids (cysteine, tyrosine, methionine, and tryptophan) and minerals (calcium, phosphorus, and iron) [4]. These granules are vastly used in the food industry for the preparation of cakes and bread. There is a high demand for nutrient-rich finger millet is on the rise in recent years. In order to meet the worldwide dietary demand, there is an immediate necessity to improve existing crops with new approaches and technologies for abiotic and biotic stress tolerance [5]. One of these methods involves the generation of transgenic crops with desired traits. In the case of millets, little genetic improvement has been done so far, specifically using wide- or cross-hybridization among the closely related species [6]. Advances in regeneration and genetic transformation have been reported in cereal crops (rice, wheat, maize, oats, and barley), very less attention given so for improvement of millets [7]. There are various explants used for in vitro regeneration in finger millets like mesocotyl, leaf base segments, root and immature inflorescence [8-11], mature seeds [12-16], shoot tips [1718]. Regeneration of whole plants from callus is a timeconsuming process as redifferentiation of shoots requires multiple sub-culturing cycles. During the prolonged culture, most of the calli lose their regeneration potential [19-21]. In addition, the use of callus tissue for transformation makes it difficult to identify competent cells for plant regeneration [22-23]. From the literatures that there is no universal recipe for efficient culture and induction of direct shoot regeneration depends on the nature of the plant organ from which the explant was derived, and is highly dependent on plant genotype. Direct regeneration is an alternative approach to establish whole plants using shoot apical meristems (SAMs) present at the apical dome. SAMs possess superior redevelopment ability and thus stimulate multiple shoots clumps within a short duration of time [2324]. Direct shoot regeneration is achieved by SAMs in monocots like rice [23- 24] wheat [25] maize [26-27] sorghum [28] pearl millet [29] oats, and barley [30-31]. 
Reports are also available on use of amino acids in media, plays an important role to improve callus induction, shoot and root formation in various plants; viz: wheat [32-33] pearl millet [34] maize [35], sorghum [36], and naga chilli [37-38]. Micropropagated plantlets are commonly subjected to genetic fidelity analysis using molecular markers to confirm their clonal identity to the mother plant [39]. Random amplified polymorphic DNA (RAPD) is an efficient marker system that makes use of arbitrary primers to cover the entire regions of the genome and has been routinely used to identify intra- and interspecies genetic variation in crops [40]. In the Present study, we report an efficient direct plant regeneration protocol for Indian finger millet genotypes $\mathrm{CO} 9$ using amino acids and organic derivates. The genetic identity of the micropropagated plantlets from the genotype $\mathrm{CO} 9$ was confirmed using RAPD markers.

\section{MATERIALS AND METHODS}

\section{Plant Material and Surface Sterilization}

Seeds of finger millet genotype CO9, obtained from the Tamil Nadu Agriculture University, Coimbatore, India. The seeds were de-husked in running tap water for $5 \mathrm{~min}$ and surface-disinfected using $0.1 \%(\mathrm{w} / \mathrm{v})$ mercuric chloride for 5 min followed by $70 \%$ (v/v) ethanol for $25 \mathrm{~s}$. The seeds were then rinsed five times with autoclaved, double-distilled water, blot dried on sterile filter paper.

\section{Culture Conditions}

Surface sterilized seeds were blot dried using autoclaved filter paper in a dry petri dish. The seeds were transferred to Petri plate containing MS medium [41] amended with sucrose $3 \%(w / v)$ and solidified with $0.8 \%$ agar. The $\mathrm{pH}$ of the medium was changed to $5.8 \pm 0.02$ using $1 \mathrm{~N} \mathrm{NaOH}$ or $\mathrm{HCl}$, before the inclusion of agar and autoclaved at $121^{\circ} \mathrm{C}$ $/ 15 \mathrm{lbs}$ pressure for 20 mins. The seeds were cultured at $25 \pm$ $2^{\circ} \mathrm{c}$ with a photoperiod of 16 hours light and 8 hours dark for 8 days.

\section{Effect of cytokinins}

Three days old in vitro germinated seedlings with Shoot Apical Meristem (SAM) 4-6 $\mathrm{mm}$ in size were used as explants. SAM explants were then transferred to Shoot Growth Medium (SGM) containing MS basal salts and vitamins supplemented with 6 - Benzylaminopurine (BAP) ,Kinetin (KIN) $(0.5,1.0,2.0,3.0$ and $4.0 \mathrm{mg} / \mathrm{L})$ individually and combination of BAP $3.0 \mathrm{mg} / 1$ and $\mathrm{KIN}$ ( 0.5, 1.0, 2.0, 3.0 and $4.0 \mathrm{mg} / \mathrm{L}$ ) concentrations for in vitro propagation. Cultures were nurtured in glass bottles $(15 \mathrm{~cm}$ height $\times 10$ $\mathrm{cm}$ diameter) and incubated at $25 \pm 2{ }^{\circ} \mathrm{c}$ in $16 / 8 \mathrm{~h}$ (light/dark) with a photosynthetic photon flux density of $50 \mu \mathrm{mol} \mathrm{m} \mathrm{m}^{-2}$ 1 supplied with cool white fluorescent lamps (Philips, Chennai, India). The shoot regeneration frequency was observed (number of explants with shoots/shoots per explants $\times 100)$ after 8 weeks, the total number of shoots per explant and average shoot length, were recorded. Shoot explants were subcultured at the $2^{\text {nd }}$ week in the same medium. The experiment was repeated thrice with each treatment using four replicates.

\section{Effect of cytokinins and coconut water}

Shoot apical meristem were cultured on MS medium containing $3 \%(\mathrm{w} / \mathrm{v})$ sucrose with $0.8 \%(\mathrm{w} / \mathrm{v})$ agar and supplemented with $5 \%(\mathrm{w} / \mathrm{v})$ coconut water and different concentrations and combinations of plant growth regulators, including BAP $0.5-4.0 \mathrm{mg} / \mathrm{L}, \quad \mathrm{KIN} \quad 0.5-4.0 \mathrm{mg} / \mathrm{L}$ and combination of BAP $3.0 \mathrm{mg} / \mathrm{L}$ and $\mathrm{KIN} 0.5-4.0 \mathrm{mg} / \mathrm{L}$.

\section{Effect of amino acid and organic derivative}

The best PGR identified $(3.0 \mathrm{mg} / \mathrm{L} \mathrm{BAP}$ and $2.0 \mathrm{mg} / \mathrm{L} \mathrm{KIN})$ from the above experiment were further examined to maximize multiple shoot regeneration. The influence of some of the essential amino acids and organic derivatives such as proline (Pro; 50, 100, 200, 300, 400, $500 \mathrm{mg} / \mathrm{L}$ ), glycine (Gly; 0.5, 1.0, 2.0, 3.0, 4.0, and $5.0 \mathrm{mg} / \mathrm{L}$ ) casein enzymatic hydrolysate (CEH; 200, 300, 400, 500, 750, or $1000 \mathrm{mg} / \mathrm{L}$ ), and $5 \%$ coconut water was systematically observed to improve shoot induction and proliferation. The cultures were incubated at $25 \pm 2{ }^{\circ} \mathrm{C}$ for $16 / 8$-h light/ dark conditions. The percentages of responding explants, mean number of shoots induced in each explant, and shoot lengths were calculated after 8 weeks incubation in light.

\section{Rooting Medium}

In vitro grown shoots $(3-6 \mathrm{~cm}$ long, 8 weeks old) were isolated individually from the multiple shoot clumps. The separated shoots were transferred to MS medium amended with different concentration of $(0.1,0.25,0.5$ and $1.0 \mathrm{mg} / \mathrm{L})$ Indole Acetic Acid (IAA), (0.1, 0.25, 0.5 and $1.0 \mathrm{mg} / \mathrm{L})$ Indole Butyric acid (IBA) and (0.1, 0.25, 0.5 and $1.0 \mathrm{mg} / \mathrm{L})$ 1-Naphthalene Acetic Acid (NAA) for rooting.

\section{Acclimatization}

Two weeks old, rooted shoots were detached from agar medium and they were thoroughly washed under running tap water and transferred to the soil mixture. Root induction frequency (number of shoots with root / total number of shoots $\times 100$ ) and mean root length (average length of three longest roots) were measured and recorded. This experiment was repeated thrice to evaluate the efficacy. Plantlets (6 -7 $\mathrm{cm}$ in length) were then acclimatized to a plastic pot containing sterilized cow dung manure and red soil $(1: 1$ ratio, $v / v$ ) and they were watered at regular intervals.

\section{RAPD Analysis}

Genomic DNA of the haphazardly selected mother plant and micropropagated plantlets were isolated from fresh leaves using CTAB method [42]. RAPD reactions were performed as described by [43]. RAPD study of both mother plant and micro propagated plantlets was performed using RAPD primers (Eurofins Genomics, Bangalore, India). PCR 
amplification was done using proflex thermocycler (Applied Biosystems, Singapore). The PCR amplified products were electrophoresed on $1.2 \%$ agarose gel in $1 \mathrm{X}$ TAE buffer at $75 \mathrm{~V}$ for $1 \mathrm{~h}$. The results were photographed using a gel documentation system (GELSTAN 1012 Economy Imaging System, Chennai, India). Lab Image ID Software, version 3.3.0 (Kapelan Bio-Imaging solutions, Leipzig, Germany) was used for the determination of amplicon size by visual comparison with $1 \mathrm{~Kb}$ ladder $(250-10000 \mathrm{bp})$.

\section{Statistical Analysis}

All the above experiments were repeated thrice with four independent replicates for each treatment. The study of variance appropriate for the design was carried out to spot the implication of difference among the treatment means. IBM SPSS Statistics version 20 Duncan's multiple range test at $\mathrm{P}<0.05$ was used to compare the treatment means.

\section{RESULT AND DISCUSSION}

\section{Effect of cytokinins on shoot regenerations}

Shoot apical meristems (SAMs) excised from 3-d-old in vitro germinated seedlings of CO 9 (Fig. 3a) were evaluated for multiple shoot induction in Shoot regeneration medium (SRM). The initial response of shoot regeneration was observed within $3 \mathrm{~d}$ and multiple shoot buds emerged from the bottom of the explants after $7 \mathrm{~d}$, without any basal callus growth (Fig. 3b). Multiple shoot induction increased spontaneously after $2 \mathrm{wk}$. Among the PGRs tested, $3.0 \mathrm{mg} / \mathrm{L}$ BAP showed $88.03 \%$ shoot regeneration frequency, $25.5 \pm 0.33$ of shoots per explant and $5.5 \pm 0.15 \mathrm{~cm}$ of shoot length (fig 1). KIN also showed a positive influence on shoot regeneration frequency of $73.67 \%$ and $14.7 \pm 0.31$ of shoots per explant (fig 1) when MS medium supplemented with 2.0 $\mathrm{mg} / \mathrm{L} \mathrm{KIN} \mathrm{which} \mathrm{is} \mathrm{less} \mathrm{compare} \mathrm{to} \mathrm{BAP.} \mathrm{However,} \mathrm{MS}$ medium amended with the combination of $3.0 \mathrm{mg} / \mathrm{L} \mathrm{BAP}$ and $2.0 \mathrm{mg} / \mathrm{L}$ KIN show highest regeneration frequency $(90.56 \%)$, multiple shoot tip per explant $(32.5 \pm 0.26)$ and multiple shoot clumps $(5.8 \pm 0.17 \mathrm{~cm})$ (fig 1$)$. BAP and KIN commonly induced multiple clumps in millets and cereals [44, 45, and 46]. In pearl millet and wheat, higher shoot proliferation was observed in medium containing BAP greater than $3.0 \mathrm{mg} / \mathrm{L} \mathrm{[25].}$

\section{Effect of cytokinins and coconut water on shoot regenerations}

Synergistic effect of cytokinins and coconut water on multiple shoot induction were tested (fig 2). Medium supplemented with (0.5-4.0 mg/L) BAP, (0.5-4.0 mg/L) KIN individually and combination of $(3.0 \mathrm{mg} / \mathrm{L}) \mathrm{BAP}$ with $(0.5-$ $4 \mathrm{mg} / \mathrm{L}) \mathrm{KIN}$ along with $5 \%$ coconut water, were tried for shoot induction. Addition of coconut water $(5 \%(w / v))$ increased the shoot number as well as shoot length (fig 2). The most significantly shoot proliferation frequency was attained in MS medium added with $3.0 \mathrm{mg} / \mathrm{L} \mathrm{BAP,} 2.0 \mathrm{mg} / \mathrm{L}$ Kin along with $5 \%$ coconut water produced $94.36 \%$. And
$37.5 \pm 0.2$ shoots per explant (fig 2). A similar result was reported by [45] in Sorghum bicolor. However, the increase in the concentration of BAP or KIN in the medium resulted in decrease in shoot number and shoot length. The shoot length varied significantly in all combination of shoot regeneration medium (SRM) (fig 2).

\section{Influence of amino acids and organic derivatives on shoot proliferation}

The addition of supplements in the media has been found to exhibit significant improvement in shoot tip initiation, proliferation, and maturation. In this study, we evaluated additives such as $\mathrm{CEH}, 5 \%$ coconut water, Gly, and Pro on improved proliferation, elongation, and maturation. The SAMs of CO 9 responded very well to amino acids supplement in a dose-dependent manner. The induction, proliferation, and elongation frequency of shooting improved quickly when amino acid levels were systematically increased in the culture medium. A higher shoot frequency (95.89\%), shoot number per explant (46.52), and shoot length $(10.8 \mathrm{~cm})$ were obtained for CO 9 genotype (Table 1), when the MS medium containing BAP $3.0 \mathrm{mg} / \mathrm{L}$, KIN $2.0 \mathrm{mg} / \mathrm{L}$ was supplemented with $300 \mathrm{mg} / \mathrm{L}$ Pro, $400 \mathrm{mg} / \mathrm{L} \mathrm{CEH}, 3.0 \mathrm{mg} / \mathrm{L}$ Gly and $5 \%$ coconut water (fig 3). In responds to this unique combination of PGRs and amino acid supplement's, the multiple shoots remained green and continued to proliferate and elongate. When the concentration of supplements were increased beyond this, there was no further improvement in regeneration, but rather a decline in induction rate, shoot number, and shoot length. Pro, $\mathrm{CEH}$ and $5 \%$ coconut water have been successfully employed for improving regeneration in rice and sorghum via high-frequency embryogenesis [47]. $\mathrm{CEH}$ is primarily act as an organic nitrogen source shows beneficially impact on multiple shoots development [48]. Multiple shoot proliferation and plant regeneration in cereals depends upon on numerous factors such as age of the explant, explant size, genotype and region are most important [49-51]. In our study, SAMs from 3-d-old seedlings were found to be optimal, along with amino acid resulting in an excellent regeneration response.

\section{Rooting and Acclimatization}

Eight-week-old shoots from shoot regeneration medium were rooted in MS medium amended with IAA, IBA, and NAA. Roots initiated spontaneously after 1 wk in MS medium devoid of PGRs. However, the inclusion of IAA $(0.1-1.0 \mathrm{mg} / \mathrm{L})$ positively influenced the rooting frequency and root length. The best root growth response in terms of frequency of root induction (100\%), mean number of roots per shoot $(9.05 \pm 0.10)$ and mean root length $(7.32 \mathrm{~cm})$ was observed when $0.25 \mathrm{mg} / \mathrm{l}$ IAA was incorporated into MS medium (Table 2; Fig. 3f.g.h). Our results were consistent with [25] in wheat. 


\section{RAPD analysis}

Finger millet plantlets propagated under in vitro conditions were subjected to clonal fidelity analysis using RAPD markers. A total of 71 monomorphic bands was generated by ten RAPD primers. The number of bands ranged from 5 (OPA7 and OPA10) to 9 (OPA1) with 7.1 bands per primer on average (Table 3 ). The amplified products ranged in size from 250 to $1990 \mathrm{bp}$ (Fig. 4). The identical banding pattern between micropropagated plants and the mother plant revealed no epigenetic variation induced under in vitro conditions.

\section{CONCLUSION}

The method demonstrates an effective and low costs protocol that helps in the rapid multiplication, large-scale production in finger millets. Influence of additives on enhanced shoot multiplication was established by the use shoot tip explants. Shoot tip proliferation, without any intervening callus phase, supposedly leads to the production of genetically stable, true-to-type plantlets. Reproducible bands were obtained from RAPD marker confirmed the genetic integrity of regenerated plantlets. Hence, this method could be used as a potential alternative en masse propagation and further for genetic transformation.

\section{ACKNOWLEDGMENTS}

This work is funded by Loyola College - Times of India, Chennai, India (Project approval code: 4LCTOI14PBB001) and UGC Research Award Scheme (F.30-1/2014/RA-201416-GE-TAM5825 SA-II). The authors are thankful to the management of Loyola College, Chennai, for providing the laboratory and infrastructure facility. Thanks to University of Madras for registration of Ph.D.

\section{REFERENCES}

[1]. B.N. Sastri, "the wealth of india: a dictionary of indian raw materials and industrial products", Vol. III (D-E), Publication and Information Directorate. CSIR, New Delhi, pp. 160-166, 1989.

[2]. M.M. O'Kennedy, J.T. Burger, F.C. Botha "Pearl millet transformation system using the positive selectable marker gene phosphomannose isomerase", Vol. 22, Issue.7. Plant Cell Reports pp.684-690, 2004.

[3]. M.M. O'Kennedy, B.G. Crampton, M. Lorito, E. Chakauya, W.A. Breese, J.T. Burger, "Expression of a $\beta$-1,3- glucanase from a biocontrol fungus in transgenic pearl millet", South African Journal of Botany, Vol. 77, Issue 2, pp.335-345, 2011.

[4]. A.M. Latha, K.V. Rao, V.D. Reddy, "Production of transgenic plants resistant to leaf blast disease in finger millet (Eleusine coracana (L.) Gaertn)", Plant Science, Vol. 169, Issue. 4, pp. 657-667, 2005.

[5]. A. Pande, S. Dosad, H.S. Chawla, S. Arora, "In vitro organogenesis and plant regeneration from seed-derived callus cultures of finger millet (Eleusine coracana)", Brazilian Journal of Botany, Vol. 38,pp.19-23,2015.
[6]. S.Plaza-Wuthrich, Z.Tadele, "Millet improvement through regeneration and transformation. Biotechnology and Molecular Biology Review”, Vol 7, pp.48-61, 2012.

[7]. S.A. Ceasar, S. Ignacimuthu, "Genetic engineering of millets: current status and future prospects", Biotechnology Letter vol. 31 pp.779-788, 2009.

[8]. T.S. Rangan, "Growth and plantlet regeneration in tissue cultures of some Indian millets: Paspalum scrobiculatum L., Eleusine coracana Gaertn. And Pennisetum typhoideum” Pers. Zeitschrift für Pflanzenphysiologie vol, 78, pp.208-216, 1976.

[9]. B.D. Mohanty, S.D. Gupta, P.D. Ghosh, "Callus initiation and plant regeneration in ragi (Eleusine coracana Gaertn.)". Plant Cell Tissue Organ Culture Vol.5, Issue. 1, pp.47-150. 1985.

[10]. L. George, S. Eapen, "High frequency plant-regeneration through direct shoot development and somatic embryogenesis from immature inflorescence cultures of finger millet (Eleusine coracana Gaertn)". Euphytica Vol.48, pp.269-274, 1990

[11]. S. Kumar, K. Agarwal, S.L. Kothari, "In vitro induction and enlargement of apical domes and formation of multiple shoots in finger millet, Eleusine coracana (L.) Gaertn and crowfoot grass, Eleusine indica (L.) Gaertn”. Current Science, Vol.81, pp.14821485,2001

[12]. J.Pius, S. Eapen, L. George, P.S. Rao, and R.S. Raut, "Performance of plants regenerated through somatic embryogenesis in finger millet (Eleusine coracana Gaertn.)," Tropical Agricultural Research and Extention,Vol 2, pp. 87-90, 1999.

[13]. P. Gupta, S. Raghuvanshi, A.K. Tyagi, "Assessment of the efficiency of various gene promoters via biolistics in leaf and regenerating seed callus of millets, Eleusine coracana and Echinochloa crusgalli",. Plant Biotech, Vol.18, pp.275-282, 2001.

[14]. N. Nethra, R. Gowda, P.H.R. Gowda, "Influence of culture medium on callus proliferation and morphogenesis in finger millet. In: Tadele, Z. (Ed.)”, New approaches to plant breeding of orphan crops in Africa. In Proceedings of an International Conference, September 19-21, 2007. Bern, Switzerland. Univ. Bern. pp. 167-178, 2009.

[15]. R. Hema, R.S. Vemanna, S. Sreeramulu, C.P. Reddy, M.S. Kumar, M. Udayakumar, "Stable expression of mtlD gene imparts multiple stress tolerance in Finger millet",. PLoS One, 2014.

[16]. S. Dosad, H.S. Chawla, "In vitro plant regeneration from mature seeds of finger millet (Eleusine coracana) through somatic embryogenesis", Indian Journal of Plant Physiology, Vol.20, pp.360-367, 2015.

[17]. S.A. Ceasar, S. Ignacimuthu, "Efficient somatic embryogenesis and plant regeneration from shoot apex explants of different Indian genotypes of finger millet (Eleusine coracana (L.) Gaertn.)", In Vitro Cellular \&Development Biology - Plant Vol. 44, pp.427-435, 2008.

[18]. L. Satish, S.A. Ceasar, J. Shilpha, A.S. Rency, P. Rathinapriya, M. Ramesh, "Direct plant regeneration from in vitro derived shoot apical meristems of finger millet (Eleusine coracana $(L$. Gaertn.)", In Vitro Cellular \&Development Biology - Plant, Vol.51, pp.192-200, 2015.

[19]. D.T. Nhut, B.V. Le, K.T.T. Van, "Somatic embryogenesis and direct shoot regeneration of rice (Oryza sativa L.) Using thin cell layer culture of apical meristematic tissue”, Journal Plant Physiology, Vol.157, pp. 559-565, 2000.

[20]. P. Lakshmanan, R.J Geijskes, L. Wang, A. Elliott, C.P.L. Grof, N. Berding, G.R. Smith, "Developmental and hormonal regulation of direct shoot organogenesis and somatic embryogenesis in sugarcane (Saccharum spp. interspecific hybrids) leaf culture", Plant Cell Reports,Vol. 25, pp. 1007-1015, 2006.

[21]. M. Dey, S. Bakshi, G. Galiba, L. Sahoo, S.K. Panda, "Development of a genotype independent and transformation 
amenable regeneration system from shoot apex in rice (Oryza sativa spp. indica) using TDZ,”. 3 Biotech, Vol. 2, pp.233-240, 2012.

[22]. M. Labra, C. Savini, M. Bracale, N. Pelucchi, L. Colombo, M. Bardini, F. Sala, "Genomic changes in transgenic rice (Oryza sativa L.) Plants produced by infecting calli with Agrobacterium tumefaciens", Plant Cell Reports, Vol. 20, pp.325-330, 2001.

[23]. S. Arockiasamy, S. Ignacimuthu, "Regeneration of transgenic plants from two indica rice (Oryza sativa L.) Cultivars using shoot apex explants", Plant Cell Reports, Vol.26, pp.1745-1753, 2007.

[24]. M.B. Sticklen, H.F. Oraby, "Shoot apical meristem: a sustainable explant for genetic transformation of cereal crops", In Vitro Cellular \&Development Biology - Plant, Vol.41, pp.187-200, 2005.

[25]. A. Ahmad, H. Zhong, W. Wang, M.B, "Sticklen Shoot apical meristem: In vitro regeneration and morphogenesis in wheat (Triticum aestivum L.)", In Vitro Cellular \&Development Biology - Plant, Vol. 38, pp.163-167, 2002.

[26]. H Zhong, C Srinivasan, MB Sticklen, "In vitro morphogenesis of corn (Zea mays L.). I. Differentiation of multiple shoot clumps and somatic embryos from shoot tips", Vol.187, pp.483-489, 1992.

[27]. H. Zhong, B. Sun, D. Warkentin, S. Zhang, R. Wu, T. Wu, M.B. Sticklen, "The competence of maize shoot meristems for integrative transformation and inherited expression of transgenes", Plant Physiology, Vol. 110, pp.1097-1107, 1996.

[28]. H. Zhong, W. Wang, M.B Sticklen, "In vitro morphogenesis of Sorghum bicolor (L.) Moench: efficient plant regeneration from shoot apices". Journal of Plant Physiology, Vol.153, pp.719-726, 1998.

[29]. P. Devi, H. Zhong, M.B. Sticklen, "In vitro morphogenesis of pearl millet [Pennisetum glaucum. (L.) R.Br.]: efficient production of multiple shoots and inflorescences from shoot apices", Plant Cell Reports Vol.19, pp. 546-550, 2000.

[30]. S. Zhang, H. Zhang, M.B. Zhang, "Production of multiple shoots from shoot apical meristems of oat (Avena sativa L.)", Journal of Plant Physiology, Vol. 148, pp. 667-671, 1996.

[31]. S. Zhang, M.J. Cho, T. Koprek, R. Yun, P. Bregitzer, P.G. Lemaux, "Genetic transformation of commercial cultivars of oat (Avena sativa L.) And barley (Hordeum vulgare L.) using in vitro shoot meristematic cultures derived from germinated seedlings" Plant Cell Reports, Vol. 18, Issue. 4, pp.959-966, 1999.

[32]. L.M. Wu, Y.M. Wei and Y.L. Zheng, "Effects of silver nitrate on the tissue culture of immature wheat embryos", Russian Journal of Plant Physiololgy, Vol. 53, Issue.4, pp. 530-534, 2006

[33]. EH Bouiamrine, M Diouri and R El-Halimi, "Somatic embryogenesis and plant regeneration capacity from mature and immature durum wheat embryos", International journal of Biological sciences, Vol.9, Issue.2, pp. 29-39, 2012

[34]. K. Oldach, A. Morgenstern, S. Rother, M. Girgi, M. O'Kennedy and H. Lörz, "Efficient in vitro plant regeneration from immature zygotic embryos of Pearl millet [Pennisettum glaucum $(L) R B r$ ] and Sorgum bicolor (L) Moench", Plant Cell Reports,Vol 20,Issue.5, pp.416-421, 2001.

[35]. H.A. El-Itriby, S.K Assem, E.H.A. Hussein, F.M. Abdel-Calil and M.A. Madkour, "Regeneration and transformation of egyptian maize inbred lines via immature embryo culture and a biolistic particle delivery syste", In Vitro Cellular and Develop BiologyPlant, Vol.39, Issue.5, pp.524-531, 2003.

[36]. S. Pola, N.S. Mani and T. Ramana, "Long-term maintenance of callus cultures from immature embryo of Sorghum bicolor", world journal of agriculture science, Vol. 5, Issue.4, pp. 415-421,
2009.

[37]. A. Sharma, V. Kumar, P Giridhar and G.A. Ravishankar, "Induction of in vitro flowering in Capsicum frutescens under the influence of silver nitrate and cobalt chloride and pollen transformation", Electronic Journal of Biotechnology, Vol. 11, Issue.2, pp. 1-6 2008.

[38]. G. Bora, H.K. Gogoi and P.J. Handique, "Effect of silver nitrate and gibberellic acid on in vitro regeneration, flower induction and fruit development in Naga Chilli", Asia-Pacific Journal of Molecular Biology and Biotechnology, Vol.22, Issue. 1, pp. 137$144,2014$.

[39]. P.K. Gupta, J.K. Roy, "Molecular markers in crop improvement: present status and future needs in India", Plant Cell Tissue and Organ Culture, Vol. 70, pp.229-234, 2002.

[40]. J. G. K. Williams, A. R. Kubelak, K. J. Livak, J. A. Rafalski., S. V. Tingey, "DNA polymorphisms amplified by arbitrary primers are useful as genetic markers", nucleic acids research, Vol.18, pp. 6531-6535, 1990.

[41]. T. Murashige, F. Skoog, "A revised medium for rapid growth and bioassays with tobacco tissue cultures" Plant Physiology, Vol.15, pp.473-497, 1962.

[42]. J.J. Doyle, J.L. Doyle, "Isolation of plant DNA from fresh tissue", Focus, Vol.12, pp.13-15, 1990

[43]. L. Satish, P. Rathinapriya, A.S. Rency, A.Ceasar, S. Pandian, R. Rameshkumar, "Somatic embryogenesis and regeneration using Gracilaria edulis and Padina boergesenii seaweed liquid extracts and genetic fidelity in finger millet (Eleusine coracana)", Journal of Applied Phycology, Vol. 28, Issue. 3, pp. 2083-2098, 2016.

[44]. S. Srivastav, S.L. Kothari, "Embryogenic callus induction and high frequency plant regeneration in pearl millet", Cereal Research Communications, Vol.30, pp. 69-74, 2002.

[45]. P. Baskaran. And N. Jayabalan. "In vitro plant regeneration and mass propagation system for Sorghum bicolor-a valuable major cereal crop", Journal of Agricultural Technology, Vol.1, pp. 345$363,2005$.

[46]. M. Ramakrishnan, S.A. Ceasar, V. Duraipandiyan, M.A. Daniel, S. Ignacimuthu, "Efficacious somatic embryogenesis and fertile plant recovery from shoot apex explants of onion (Allium cepa. L.) ", In Vitro Cellular \& Developmental Biology - plant, Vol. 49, pp.285-293, 2013.

[47]. K. Ozawa, A. Komamine, "Establishment of a system of highfrequency embryogenesis from long-term cell suspension cultures of rice (Oryza sativa L.). Theoretical and Applied Genetics, Vol.77, pp.205-211, 1989

[48]. V.K. Sharma, R. Hänsch, R.R. Mendel and J. Schulze, "A highly efficient plant regeneration system through multiple shoot differentiation from commercial cultivars of barley (Hordeum vulgare L.) Using meristematic shoot segments excised from germinated mature embryos", Plant Cell Reports, Vol. 23, pp. 916, 2004.

[49]. M. Cheng, T. Hu, J Layton, C.N .Liu, J.E. Fry, "Desiccation of plant tissues post-Agrobacterium infection enhances T-DNA delivery and increases stable transformation efficiency in wheat", In Vitro Cellular \& Developmental Biology - plant, Vol. 39, pp. 595-604, 2003.

[50]. M. Ramesh, V. Murugiah, A.K, "Gupta Efficient in vitro plant regeneration via leaf base segments of indica rice (Oryza sativa L)", Indian Journal of Experimental Biology, Vol.47, pp.68-74, 2009.

[51]. A. Piqueras, N. Alburquerque, K.M. Folta, "Explants used for the generation of transgenic plants" In: Kole C, Michler CH, Abbott AG, Hall TC (eds) Transgenic crop plants. Springer, Berlin Heidelberg, pp 31-56, 2010 
Table 1 Effect of BAP, Organic Derivatives and Amino acid supplements on multiple shoot proliferation in finger millet genotype $\mathrm{CO} 9$ after 8 wks of incubation in the light

\begin{tabular}{|c|c|c|c|c|c|c|c|c|}
\hline 3 & 2 & 50 & 0.5 & 100 & 5 & 60.35 & $19.65 \pm 0.2^{f}$ & $6.82 \pm 0.1^{j}$ \\
\hline 3 & 2 & 100 & 1 & 200 & 5 & 67.46 & $23.45 \pm 0.2^{\mathrm{e}}$ & $7.24 \pm 0.4^{\text {hi }}$ \\
\hline 3 & 2 & 400 & 4 & 500 & 5 & 79.74 & $29.31 \pm 0.5^{\mathrm{c}}$ & $8.60 \pm 0.6^{\mathrm{h}}$ \\
\hline 3 & 2 & 500 & 5 & 600 & 5 & 64.52 & $24.48 \pm 0.4^{\mathrm{d}}$ & $7.21 \pm 0.5^{\text {hi }}$ \\
\hline
\end{tabular}

Table 2 Effect of Auxins on Root formation of finger millet genotype CO9

Auxins mg/L Percentage of Rooting (\%) $\quad$ No. of Roots per Shoot

\section{Root Length (cm)}

$\begin{array}{cccc}\text { IAA } & & & \\ \mathbf{0 . 1} & 81.83 & 4.44 \pm 0.13^{\mathrm{e}} & 3.58 \pm 0.08^{\mathrm{f}} \\ \mathbf{0 . 2 5} & 100 & 9.05 \pm 0.10^{\mathrm{a}} & 7.32 \pm 0.06^{\mathrm{b}} \\ \mathbf{0 . 5} & 98.26 & 8.61 \pm 0.03^{\mathrm{b}} & 4.443 \pm 0.7^{\mathrm{e}} \\ \mathbf{1 . 0} & 92.59 & 5.45 \pm 0.06^{\mathrm{d}} & 2.34 \pm 0.07^{\mathrm{g}} \\ \mathbf{I B A} & & & \\ \mathbf{0 . 1} & & & 3.90 \pm 0.05^{\mathrm{f}} \\ \mathbf{0 . 2 5} & 60.96 & 6.56 \pm 0.10^{\mathrm{c}} & 4.27 \pm 0.07^{\mathrm{e}} \\ \mathbf{0 . 5} & 66.61 & 8.22 \pm 0.10^{\mathrm{b}} & 3.20 \pm 0.08^{\mathrm{f}} \\ \mathbf{1 . 0} & 76.19 & 6.37 \pm 0.09^{\mathrm{c}} & 3.00 \pm 0.11^{\mathrm{f}} \\ \mathbf{N A A} & 69.43 & 4.71 \pm 0.07^{\mathrm{e}} & \\ \mathbf{0 . 1} & & & 1.94 \pm 0.07^{\mathrm{h}} \\ \mathbf{0 . 2 5} & & & 2.45 \pm 0.01^{\mathrm{d}} \\ \mathbf{0 . 5} & & 3.40 \pm 0.07^{\mathrm{f}} & 2.51 \pm 0.10^{\mathrm{g}} \\ \mathbf{1 . 0} & 64.62 & 3.70 \pm 0.11^{\mathrm{f}} & 2.18 \pm 0.04^{\mathrm{g}}\end{array}$

Table 3 List of RAPD primer sequences with the number and size of amplified fragments generated in genotype CO 9 of finger millet mother plant and micropropagated plantlets.

\begin{tabular}{cccc}
\hline & Genotype & & CO 9 \\
\hline Primer code & Primer sequence (5'-3') & No. of scorable bands & Range of band sizes (bp) \\
OPA 1 & CAGGCCCTTC & 9 & $460-1500$ \\
OPA 2 & TGCCGAGCTG & 8 & $430-1450$ \\
OPA 3 & AGTCAGCCAC & 7 & $530-1600$ \\
OPA 4 & AATCGGGCTG & 7 & $640-1500$ \\
OPA 5 & AGGGGTCTTG & 8 & $300-1500$ \\
OPA 6 & GGTCCCTGAC & 8 & $490-1990$ \\
OPA 7 & GAAACGGGTG & 5 & $520-1900$ \\
OPA 8 & GTGACGTAGG & 8 & $250-1480$ \\
OPA 9 & GGGTAACGCC & 6 & $360-1490$ \\
OPA1 0 & GTGATCGCAG & 5 & $330-1350$ \\
\hline
\end{tabular}




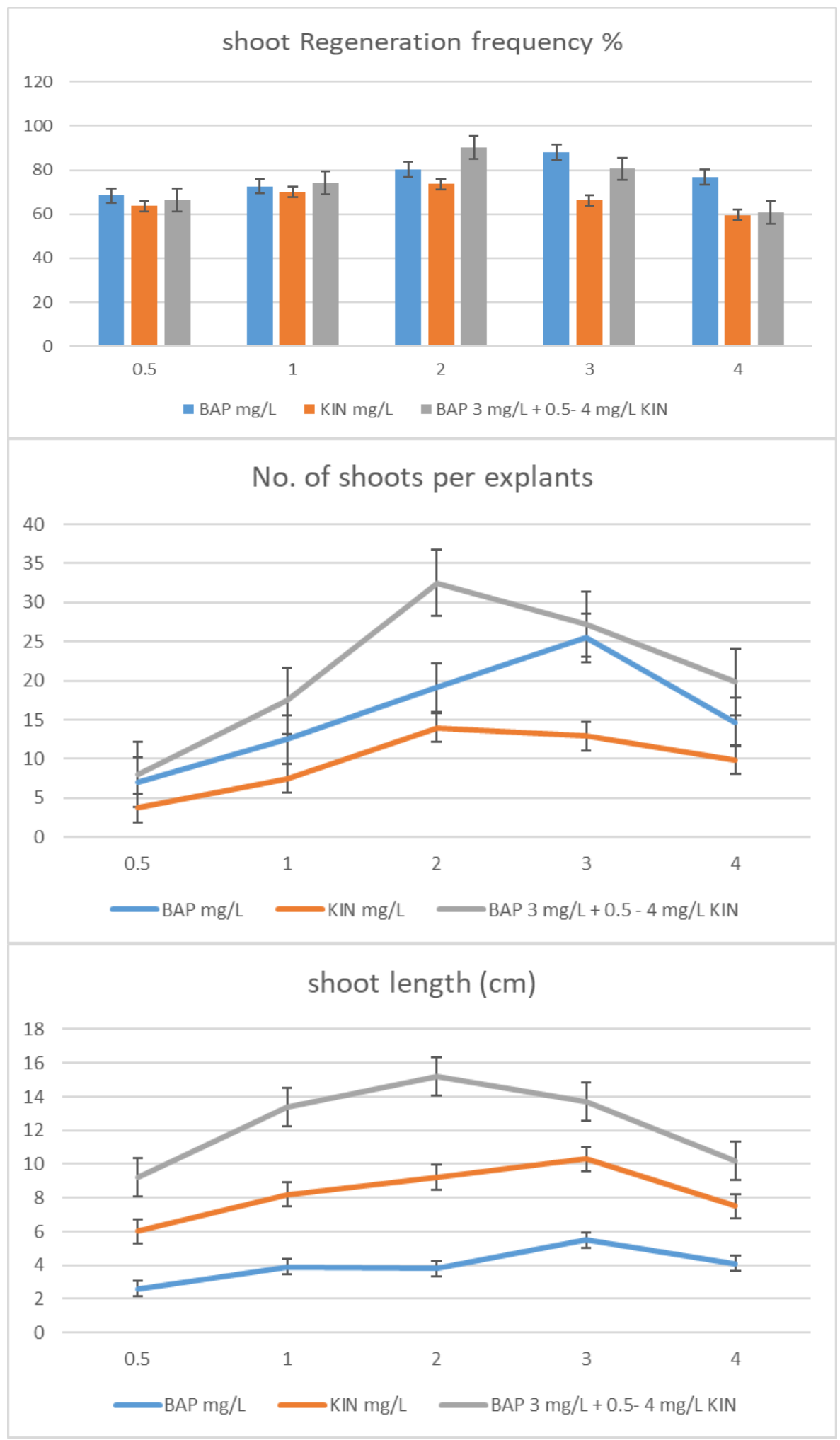

Figure 1 Effect of Cytokinins in Direct Regeneration of finger Millet genotype CO 9. Values represent mean \pm SE of individual treatments obtained from three repeated experiments. Each treatment consisted of four replicates with ten explants per replicate 


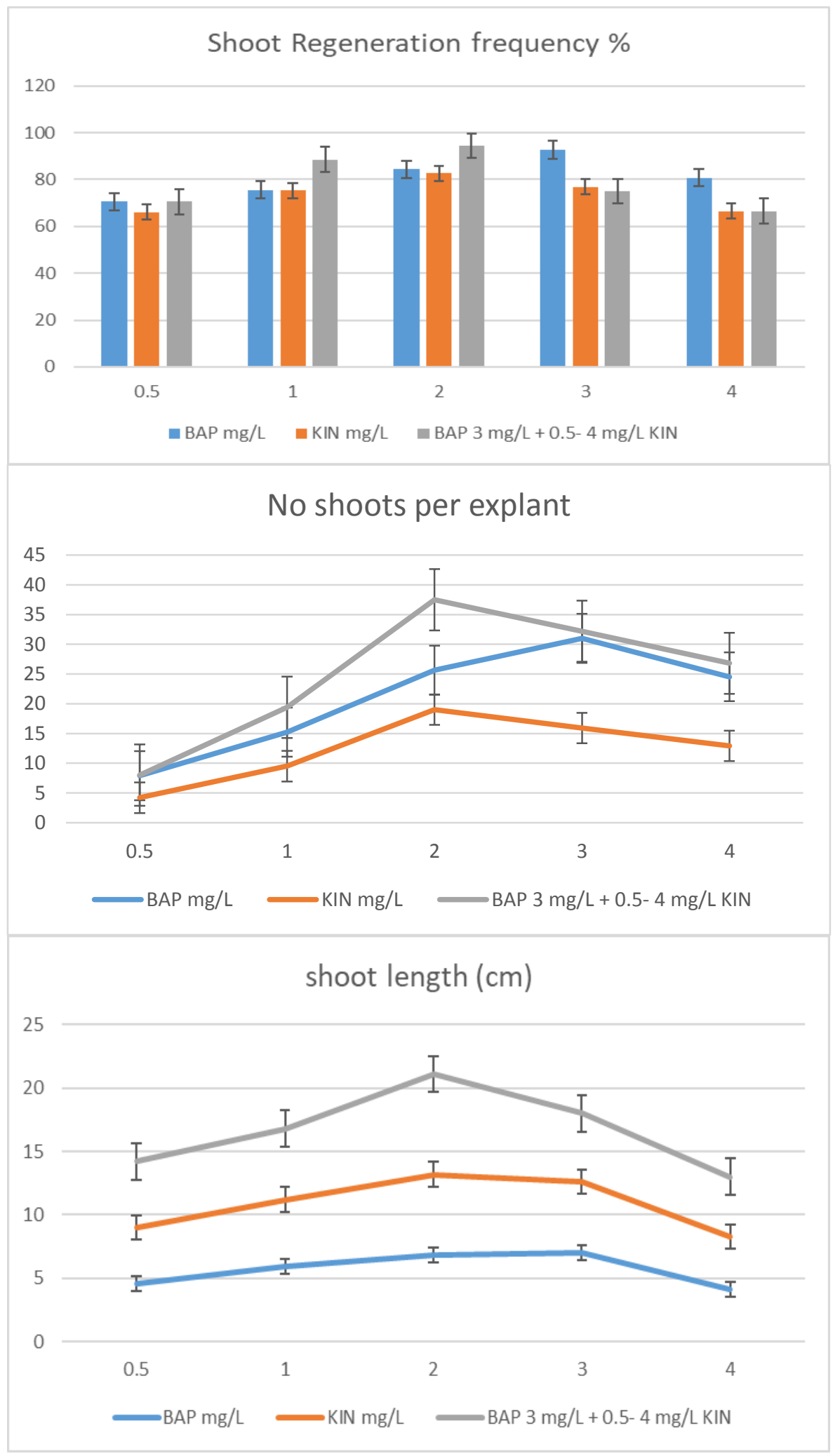

Figure 2 Effect of Cytokinins along with 5\% coconut water in Direct Regeneration of finger Millet genotype CO 9 Values represent mean $\pm \mathrm{SE}$ of individual treatments obtained from three repeated experiments. Each treatment consisted of four replicates with ten explants per replicate 

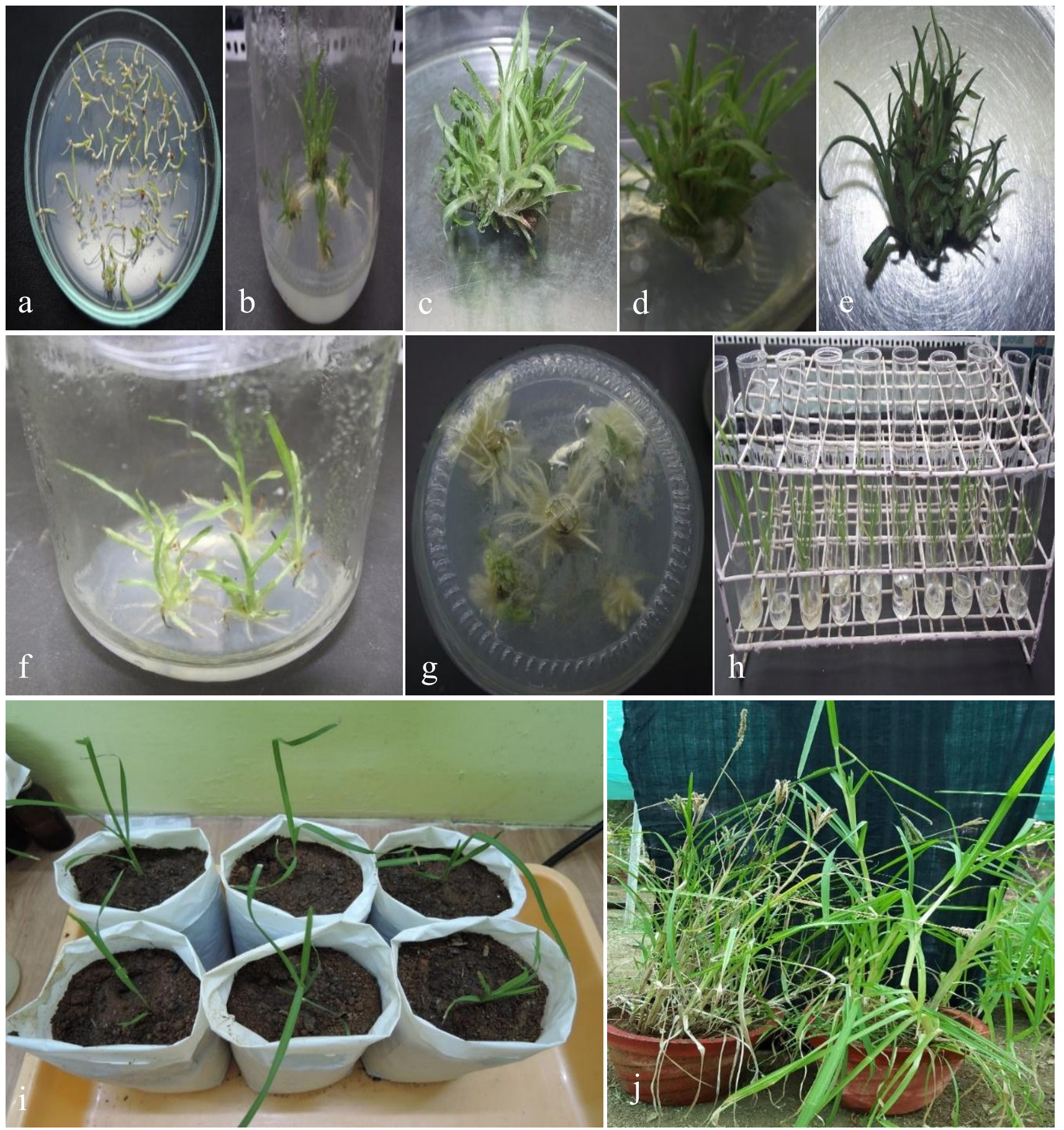

Figure 3 Direct regeneration from shoot apical meristems of E. coracana. (a) Initiation of shoot apical meristems (3-4 mm) from mature seeds germinated on MS medium after $3 \mathrm{~d}$; (b) Induction of multiple shoots in shoot regeneration medium(SRM) containing MS basal salts and vitamins supplemented with with $3 \mathrm{mg} / \mathrm{L}$ 6-Benzyl Amino Purine (BAP), $2 \mathrm{mg} / \mathrm{L} \mu \mathrm{M}$ Kinetin and $5 \%$ coconut water in combination with $300 \mathrm{mg} / \mathrm{L}$ proline, $400 \mathrm{mg} / \mathrm{L}$ casein enzymatic hydrolysate, and $3 \mathrm{mg} / \mathrm{L}$ glycine.; (c) Proliferation of shoots in SRM after 4 wk; (d) Multiple shoot regeneration in SRM after 6 wk; (e) Elongated shoots of CO 9 in SRM after 8 wk; (f,g) Rooting in MS medium supplemented with 0.25 mg/l IAA after $1 \mathrm{wk}$; (h) Rooting in liquid MS for 1 wk (i) Acclimatized plantlets in grow bags containing sterile red soil and manure $(1: 1, v / v)$; (j) Seed set of micropropagated plants grown in the field. 


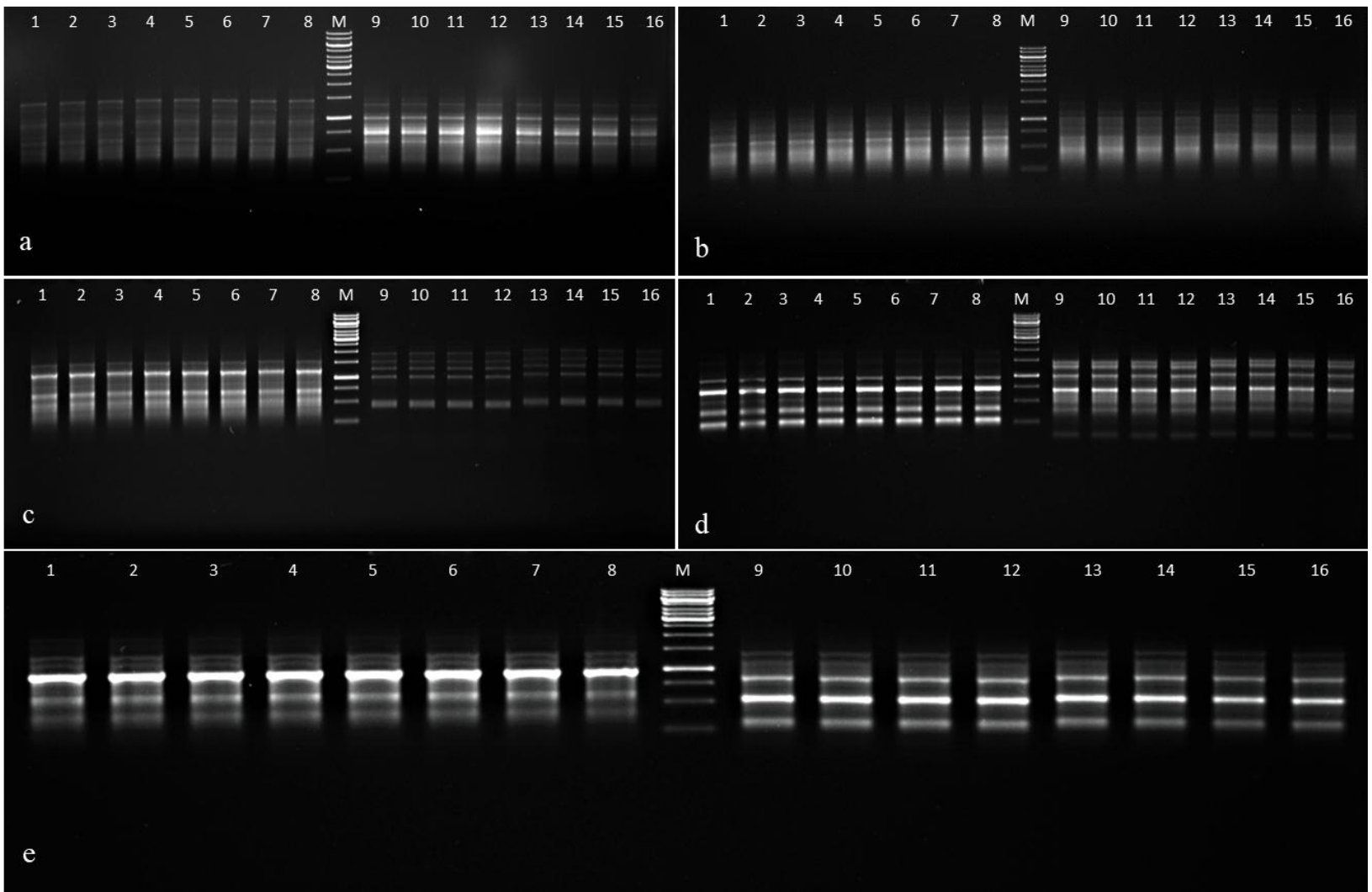

Figure 4 Assessment of genetic fidelity of the mother plant and micropropagated plantlets of Eleusine coracana using RAPD markers. (a)RAPD primers 1 (left) and 2 (right); (b) RAPD primers 3 (left) and 4 (right); (c) RAPD primers 5 (left) and 6 (right) (d) RAPD primers 7 (left) and 8 (right); (e) RAPD primers 9 (left) and 10 (right) The same seven ex vitro plants are represented in the same order in each of the 10 gel halves. In each panel, lanes 1 and 9 are mother plants; lanes 2-8 and 10-16 are ex vitro plants; lane $\mathrm{M}$ is $1 \mathrm{~Kb}$ DNA marker.

\section{Author's Profile}

Dr.R.Ravindhran is presently working as Associate professor and Head of the Department, Department of plant Biology and Biotechnology, Loyola College, Chennai-600034. He has 20 years of experience in teaching and research. To his credit 7 students have completed Ph.D. under his guidance. His research team involved in developing bio fortified millets through genetic engineering and genome editing using CRISPR/Cas 9.

G.Atul babu is a research scholar in the Department of Plant Biology and Biotechnology, Loyola College, Chennai-600034. He has completed master's degree in Biotechnology. His area of research is plant tissue culture and molecular Biology. 